УДК 664.78.032

DOI https://doi.org/10.15673/swonaft.v2i84.1879

\title{
ЗЕРНО ГОЛОЗЕРНОГО ВІВСА ТА ГОЛОЗЕРНОГО ЯЧМЕНЮ. ОСОБЛИВОСТІ ТЕХНОЛОГІЧНИХ ВЛАСТИВОСТЕЙ ЗЕРНА
}

Соц С.М., канд. техн. наук, доцент, Чумаченко Ю.Д., канд.техн.наук, доцент, Кустов І.О., канд.техн.наук, доцент, Кузьменко Ю.Я., канд.техн.наук, ст. викладач Одеська національна академія харчових технологій, м. Одеса

Copyring (C) 2020 by author and the journal «Scientific Works»

This work is licensed under Vthe Creative Commons Attribution International License (CC By). http://creativecommons.org/licenses/by/4.0

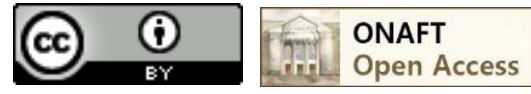

Анотація. Розглянуто основні переваги голозерного зерна над традиційними формами, щุо обумовлює перегляд та наукове обгрунтування структури, режимів, технологічного прочесу 3 розширенням асортименту та можливістю виробництва продуктів з підвищеною харчовою иінністю. Предметом дослідження є зразки зерна голозерного ячменю сорту «Ахіллес» та голозерного вівса сортів «Саломон» $i$ «Самуель» 2017-2018 року. Якість зерна голозерного вівса і продуктів його переробки оцінювали хімічними, біохімічними та фізико-технологічними показниками.

В ході досліджень визначали найбільш вагомі для круп'яної промисловості та виробництва високоякісних харчових продуктів показники - геометричні характеристики, вирівняність, вміст дрібного зерна, натуру, масу 1000 зерен, плівчастість, масову частка білка, жиру, крохмалю, мінеральних речовин тощь. Результати досліджень порівнювали із даними, які було отримано при попередніх дослідженнях, що дозволить в подальшому розширити існуючу класифікацію зерна ячменю та вівса саме як харчового зерна.

Ключові слова: голозерний овес, голозерний ячмінь, зерно продовольчих потреб, технологічні властивості, підвищення харчової цінності, спрощення технологічного процесу.

\section{GRAIN OF NAKED OATS AND NAKED BARLEY. FEATURES OF TECHNOLOGICAL PROPERTIES OF GRAIN}

\author{
S. SOTS, Ph.D., Associate Professor, Y. Chumachenko, Ph.D., Associate Professor, \\ I. Kustov, Ph.D., Associate Professor, Y. Kuzmenko, Ph.D., Senior Lecturer \\ Odessa National Academy of Food Technologies, Odesa
}

\begin{abstract}
Oat grain among other cereals is characterized by the most valuable chemical composition - high content of protein, fat, digestible carbohydrates, vitamins minerals and more. Oat grain contains all the essential amino acids for the human body, which indicates the high biological value of the products derived from it.Today, the world is transitioning to less complicated and more energy-efficient technologies, which allows to obtain products with higher yields and nutritional value. The basis for the creation of food with improved properties is, as a rule, new specially grain. Among such crops, the naked forms of barley and oats can be distinguished. Today the study of processes of naked varieties of cereal crops in food products is very important for the national grain processing industry.

The main advantages of naked grain over traditional forms are considered, which determines the review and scientific substantiation of the structure, modes, technological process with the extension of the range and the possibility of production of products with high nutritional value. It use will reduce the technological process, increase the yield of finished products and increase the content of important components for the body. The use of naked varieties of oats and barley makes it possible to shorten the technological process, significantly increase the yield of finished products and increase the content of important for the human body.

The subject of the study are examples of hulles barley variety "Achilles" and naked oat varieties "Salomon" and "Samuel" 2017...2018 year. The quality grain was evaluated by chemical, biochemical and physicaltechnological parameters. The technological properties of modern samples of Ukrainian breeding grain of naked oats and hulles barley, their chemical composition are studied. During the research, the most important
\end{abstract}


indicators for groats industry and production of high-quality foodstuffs were determined - geometric characteristics, uniformity, content of small grains, volume weight, 1000 grains weight, hoodness, mass fraction of protein, fat, starch, minerals, etc. The results of the studies were compared with those obtained in previous studies, which will further expand the existing classification of barley and oats as food grains.

Keywords: naked oats, hulles barley, grain of food needs, technological properties, increase of nutritional value, simplification of technological process.

Продукти переробки вівса в Україні за останні десятиліття стали традиційними для більшості населення нашої країни. Зерно вівса серед інших злакових культур характеризується найбільш цінним хімічним складом - високим вмістом білка, жиру, засвоюваних вуглеводів, вітамінів мінералів тощо. В зерні вівса присутні усі незамінні для організму людини амінокислоти, що говорить про високу біологічну цінність отриманих з нього продуктів. Зерно вівса та продукти його переробки містять багато жиру $(5,0 \ldots 7,0 \%)$, при цьому частка важливих для організму людини полі ненасичених жирних кислот складає $70 \ldots 80 \%$, що дозволяє говорити про високу біологічну ефективність вівсяного зерна. Серед вуглеводного комплексу, окрім крохмалю та інших речовин, важливе значення має некрохмальний полісахарид $\beta$-глюкан. Дана речовина відноситься до розчинних харчових волокон які мають здатність регулювати рівень холестерину та цукру у крові та впливати на регулювання ваги тощо, тобто $\epsilon$ необхідною речовиною у раціоні харчування людини. За різними даними серед інших круп і круп'яних продуктів за вмістом харчових волокон вівсяна крупа посідає одне 3 провідних місць маючи їх кількість на рівні 7...8 \%. Переробка зерна вівса за існуючими традиційними технологіями за рахунок використання складного та протяжного технологічного процесу не дозволяє використовувати весь закладений природою потенціал вівсяного зерна [1-7].

В нашій країні майже відсутній такий важливий продукт як вівсяні харчові висівки, що традиційно отримують при здрібнюванні вівсяного зерна. Основною метою при виробництві усіх видів борошна в нашій країні є отримання максимального виходу подрібненого продукту, тому, як правило, висівки, що отримують після здрібнювання не використовується як цінний харчовий продукт. В країнах ЕС, Америки, особливо США, вівсяні висівки з останньої чверті XX ст. увійшли в асортимент найбільш корисних і дієтичних продуктів. Їх особливістю є високу масову частку харчових волокон (до 16,0 \%) особливо корисних для організму людини $\beta$-глюканів (масова частка $5,5 \ldots 23,0 \%$ ), високу масову частку білка $(4,0 \ldots 8,0 \%)$ та відповідно збагачений амінокислотний склад тощо $[22,23,24,25,26,27,28]$.

Існуючі технології не дозволяють отримувати при переробці вівса високий вихід готової продукції, який не перевищує $55 \ldots 65$ \% навіть при застосуванні найбільш сучасних плівкових сортів вівса із покращеними властивостями. Також виникає необхідність складування, зберігання та утилізування значної кількості лузги, кількість якої, в залежності від сортових особливостей зерна, що переробляється, може сягати $20 \ldots 40 \%$ [2]. Технологічні процеси переробки плівчастого вівса є одними 3 найбільш складних у круп'яному виробництві - включають у себе воднотеплову обробку методом гарячого кондиціювання, лущення на декількох системах, сортування продуктів лущення, складне круповідділення, шліфування тощо, все це призводить до значної енергозатратності технології та необхідності значних виробничих площ для іiі реалізації. На різних етапах переробки, особливо при пропарюванні зерна відбувається зменшення харчової цінності зерна та відповідно продуктів його переробки - простежується зменшення масової частки білка, крохмалю, вітамінів тощо.

Основним асортиментом продуктів, що отримують при переробці зерна ячменю круп'яного призначення (зерно 1 класу відповідно до ДСТУ 3769-98 [8]) на вітчизняних заводах $є$ два види круп перлові та ячні [1,2]. На основі аналізу існуючих технологій переробки ячменю можна зробити висновок, що виробництво ячмінних продуктів потребує використання 4 лущильних систем, 3 шліфувальних систем, 3 полірувальних системи, 5 сортувальних систем та 7 систем контролю ядра на різних етапах у повітряних сепараторах, для виробництва крупи ячної передбачено 4 системи для подрібнення шліфованого ядра та додаткова шліфувальна систему для продуктів подрібнення середньої фракції. Вихід круп перлових не перевищує $45 \%$, круп ячних - $65 \%$ [1]. Складний технологічний процес призводить до того, що із зерна ячменя видаляється значна частина корисних для організму людини речовин - протеїнів, ліпідів, клітковини, мінеральних речовин [9].

Сьогодні у світі відбувається перехід до менш складних та більш енергоефективних технологій, що дозволяє отримувати продукти із підвищеним виходом та харчовою цінністю. Основою для створення нових продуктів харчування із покращеними властивостями $\epsilon$, як правило, нові спеціально виведені селекціонерами зернові культури. Серед нових яких можна виділити голозерні форми ячменю та вівса [10-11]. Основними перевагами голозерного зерна над традиційними формами є відсутність жорстких квіткових плівок, міцно зв'язаних з поверхнею зернівки (20...40 \% у плівчастих форм вівса та $10 \ldots 15 \%$ у ячменя), які, як правило, видаляються при обмолочуванні та високоякісний хімічний склад 
зерна, що і формує основну привабливість голозерного ячменю та голозерного вівса для виробництва продуктів харчування. Поява нових сортів круп’яних культур української селекції обумовлює перегляд та наукове обгрунтування структури, режимів, технологічного процесу з розширенням асортименту та можливістю виробництва продуктів 3 підвищеною харчовою цінністю. Ї̈̈ використання дасть можливість скоротити технологічний процес, підвищити вихід готової продукції та збільшити вміст важливих для організму компонентів. Використання голозерних сортів вівса та ячменю дає змогу скоротити технологічний процес, значно підвищити вихід готової продукції та збільшити у ній вміст таких важливих для організму людини компонентів як білки, $\beta$-глюкани, слизисті речовини, що дозволить забезпечити створення науково обгрунтованих технологій виробництва продуктів 3 підвищеною харчовою цінністю.

Метою даного дослідження $є$ визначення технологічних властивостей зерна сучасних зразків української селекції зерна голозерного вівса та голозерного ячменю, їх хімічного складу для встановлення можливостей отримання при їх переробленні високоякісних продуктів харчування при потенційному збільшенні кількісних значень виходів готової продукції. В ході досліджень визначали найбільш вагомі для круп'яної промисловості та виробництва високоякісних харчових продуктів показники - геометричні характеристики, вирівняність, вміст дрібного зерна, натуру, масу 1000 зерен, плівчастість, масову частка білка, жиру, крохмалю, мінеральних речовин тощо. Результати досліджень порівнювали із даними, які було отримано при попередніх дослідженнях (2011...2014 роки), що дозволить в подальшому розширити існуючу класифікацію зерна ячменю та вівса саме як харчового зерна. Геометричні властивості зерна $є$ визначальними при виборі оптимальних характеристик робочих органів технологічного обладнання та режимів переробки. Зерно голозерного вівса та голозерного ячменю, як правило, характеризується меншими геометричними характеристиками в порівнянні із плівчастим зерном, однак має приблизно рівну довжину, ширину i товщину із лущеним ядром плівчастого зерна. Попередніми дослідженнями визначено, що зерно голозерного ячменю сорту «Ахіллес» характеризувалося довжиною 7,0...9,1 мм, товщиною 2,0...4,3 мм та товщиною $1,7 \ldots 3,8$ мм, що на $0,3 \ldots 1,1$ мм є меншим в порівнянні із плівчастим зерном ячменю. Зерно голозерного ячменю нового врожаю 2017...2018 року за своїми геометричними характеристиками не суттєво відрізняється від попередньо досліджених зразків і має довжину 7,2..9,0 мм, ширину $2,1 \ldots 4,0$ мм, товщину $1,7 \ldots 3,3$ мм. Зерно голозерного вівса врожаїв 2011..2014 років характеризувалося довжиною у діапазоні 5,7 ..8,6 мм, товщиною 1,2...3,1 мм та шириною - 1,6...3,7 мм, тоді як зерно плівчастого вівса мало довжину 9,6...15,0 мм, товщину 2,1...2,8 мм та ширину 2,5...3,6 мм. Встановлено, що зерно врожаю $2017 . .2018$ року сорту «Саломон» має геометричні характеристики довжину, ширину та товщину які не перевищують раніше визначених меж отриманих при попередніх дослідженнях. Довжина зернівки 6,1..8,5 мм, ширина 2,5...3,6 мм, товщина - 1,5...2,7 мм. В той час як зерно голозерного вівса сорту «Самуель» характеризується дещо більшими показниками: довжиною 6,8...8,9 мм, товщиною 2,4...3,6 мм та шириною 2,0...3,7 мм. Розглядаючи отримані дані геометричних характеристик можна відмітити, що вони в залежності від року і умов вирощування змінюються у відносно стабільних межах, що дозволяє використовувати раніше визначені параметри робочих органів зерноочищувального обладнання при організації процесу очищення досліджуваного зерна.

Таблиця 1 - Гранулометрична характеристика досліджуваного зерна голозерного вівса сорту «Саломон»

\begin{tabular}{|c|c|c|c|c|c|}
\hline \multirow{3}{*}{$\begin{array}{c}\text { Рік } \\
\text { вирощування }\end{array}$} & \multicolumn{5}{|c|}{ Набір сит, схід/прохід, \% } \\
\hline & - & $2,2 \times 20$ & $2,1 \times 20$ & $2,0 \times 20$ & $1,8 \times 20$ \\
\hline & $2,2 \times 20$ & $2,1 \times 20$ & $2,0 \times 20$ & $1,8 \times 20$ & - \\
\hline \multicolumn{6}{|c|}{ сорт вівса «Саломон» } \\
\hline 2017 & 6,4 & 54,9 & 26,3 & 8,2 & 4,2 \\
\hline 2018 & 7,9 & 56,6 & 23,6 & 7,7 & 4,2 \\
\hline \multicolumn{6}{|c|}{ сорт вівса «Самуель» } \\
\hline 2017 & 7,7 & 56,5 & 25,3 & 5,7 & 4,8 \\
\hline
\end{tabular}

Аналіз фракційного складу зерна голозерного вівса нових врожаїв обох сортів та зерна голозерного ячменю(табл. 1, табл. 2) показав, що майже 75...80 \% всього зерна досліджуваних знаходиться у фракції $2,2 \times 20 / 2,0 \times 20$ мм (голозерний овес) і 2,4×20/2,0×20 мм (голозерний ячмінь). Кількість зерна, отриманого проходом сита 1,8×20 мм (голозерний овес) і 2,0×20 мм, яке класифікується як дрібне для досліджуваних зразків не перевищувало 5,0 \%, що задовольняє діючим вимогам для вівса та ячменю призначених для круп'яного використання. У голозерного зерна фактично на поверхні відсутні квіткові плівки, однак як було встановлено при попередніх дослідженнях не стовідсоткова ефективність обмолочування при 
збиранні та наявність незначної частини плівчастого вівса у зерновій масі голозерного дають підставу розглядати показник плівчастості для визначення якості голозерного вівса. Наявність плівчастого і необрушеного зерна у суміші голозерного вівса залежить від багатьох факторів - агрокліматичних умов вирощування, сортових особливостей, ефективності вимолочування зерна тощо. При попередніх дослідженнях встановлено, що плівчастість голозерного вівса змінювалася у межах $5 . .7$ \%, в той час як плівчастість звичайного вівса складає $23 . .25 \%$.

Таблиця 2 - Гранулометрична характеристика досліджуваного зерна голозерного ячменю

\begin{tabular}{|c|c|c|c|c|}
\hline \multirow{2}{*}{$\begin{array}{c}\text { Рік } \\
\text { вирощування }\end{array}$} & \multicolumn{4}{|c|}{ Набір сит, прохід/ схід, \% } \\
\cline { 2 - 5 } & $\frac{-}{2,4 \times 20}$ & $\frac{2,4 \times 20}{2,2 \times 20}$ & $\frac{2,2 \times 20}{2,0 \times 20}$ & $\frac{2,0 \times 20}{-}$ \\
\hline \multicolumn{5}{|c|}{ сорт ячменю «Ахіллес» } \\
\hline 2017 & 11,2 & 46,7 & 36,7 & 5,4 \\
\hline 2018 & 12,5 & 45,8 & 37,4 & 4,3 \\
\hline
\end{tabular}

Показник плівчастості для досліджуваного зерна голозерного обох сортів вівса складає у межах $8,0 \ldots 8,5 \%$, що пов'язано із більшою кількістю звичайного плівчастого вівса який присутній у зерні голозерного вівса. Плівчастість зерна голозерного ячменю при попередніх дослідженнях змінювалася у межах 1,4...3,5\%. В зерні голозерного ячменю 2017...2018 року даний показник $\epsilon$ більшим i складає $5,1 \%$. За рахунок того, що таке плівчасте зерно різко відрізняється за геометричними характеристиками від основного (голозерного), його можливо ефективно видаляти на етапі зерноочищення із застосуванням ситових сепараторів, трієрів, падді-машин 3 подальшим його накопиченням та використанням. Як показали попередні дослідження враховуючи незначну кількість плівчастого і необрушеного зерна у суміші голозерного ячменю, його можна не вилучати так як при шліфуванні достатньо ефективно проходить вилучення оболонок 3 такого зерна. Важливими технологічними показниками за якими попередньо можливо оцінити вихід та деякі якісні показники готової продукції є маса 1000 зерен та натура. Попередніми дослідженнями визначено, що зерно голозерного ячменю та вівса завдяки відсутності квіткових плівок характеризується високими значеннями натури. Визначено що натура голозерного ячменю складає 738...750 г/л, голозерного вівса 680-695 г/л, що більше значень натури плівчастого зерна. Натура зерна голозерного ячменю сорту «Ахіллес» врожаю 2017...2018 року складає 735...750 г/л. Натура зерна досліджуваних сортів голозерного вівса складає 685...705 г/л для сорту «Саломон» та 687...710 г/л для сорту «Самуель», що знаходиться у межах значень характерних для голозерного вівса отриманих при попередніх дослідженнях. Показник маси 1000 зерен суттєво залежить від сортових особливостей зерна та умов вирощування, для плівчастого вівса його значення змінюється у межах $24 . .28$ г, для голозерного - 23...26 г. Для ячменю даний показник знаходиться на рівні 20...50 г для плівчастого зерна та $41 \ldots 47$ г - для голозерного. Для зерна 2017...2018 року вирощування маса 1000 зерен змінюється у межах 25...27 г для сорту «Саломон», $27 . .29$ г для сорту «Самуель» та 45...48 г для сорту голозерного ячменю «Ахіллес». Отримані значення натури та маси 1000 зерен говорять про можливість отримання високого виходу готової продукції при переробці досліджуваного зерна. Для продовольчого вівса та ячменю існують обмеження за вмістом характерних домішок в зерновій суміші. Для вівса масова частка смітної домішки не повинна перевищувати 3,0 \%, зернової - 7,0 \% (зерно III класу), в зерні ячменю продовольчого призначення масова частка сміттєвої домішки повинен складати не більше 2,0 \%, зернової - 7,0 \%. Досліджувані зразки зерна голозерного ячменю та голозерного вівса за вмістом сміттєвої і зернової домішки задовольняють обмежувальним вимогам для продовольчого зерна. На основі проведеного аналізу можна зробити висновок, що зерно голозерного ячменю сорту «Ахіллес» та голозерного вівса сортів «Саломон» i «Самуель» володіють високим круп’яним потенціалом. Як показує аналіз попередніх досліджень при переробці зерна із такими показниками можна отримувати вихід готової продукції на рівні 75 ...85 \%, що також є важливим і для виробництва продуктів з підвищеною харчовою цінністю високий вихід для яких $€$ пріоритетним. На наступному етапі досліджень проводили визначення особливостей деяких показників хімічного складу досліджуваних зразків зерна голозерного ячменю та голозерного вівса. При попередніх дослідженнях зерна голозерного ячменю сорту «Ахіллес» визначено, що даний сорт ячменю характеризується підвищеною масовою часткою білка 14,6...15,8 \%. Для голозерного вівса сорту «Саломон» врожаїв 2011..2014 року також характерною є підвищена масова частка білка в зерні $14,6 \ldots 15,5 \%$, що в 1,2 ..1,3 рази перевищує масову частку білка у плівчастому зерні $-12,3 \ldots 12,5 \%$. В той же час масова частка білка в зерні голозерного ячменю $2017 \ldots 2018$ року складає $15,7 \ldots 16,1 \%$, а для голозерного вівса сортів «Саломон» та «Самуель» відповідно 14,9...15,2 \% та 15,0..15,4 \%, що знаходиться у межах значень які було отримано для голозерного вівса при попередніх дослідженнях. 
Зерно вівса характеризується підвищеною масовою часткою жиру кількість яких може складати до $6 . .7 \%$, ячмінь в порівнянні з зерном вівса вміщує значно меншу масову частку жиру $-2,4 \%$. Продукти переробки вівса вміщують приблизно таку ж саму масову частку жиру що і необроблене зерно 6,0...6,2 \%, продукти переробки ячмінного зерна крупи перлові та ячні характеризуються низькою масовою часткою жиру - 1,1 та 1,3\% відповідно [12]. При попередніх дослідженнях визначено, що масова частка жиру у зерні голозерного ячменю сорту «Ахіллес» складає від 2,1 до 3,8 \%, голозерного вівса сорту «Саломон» характерним є масова частка жиру на рівні 5,8...6,5 \%, що притаманно для лущеного ядра плівчастого вівса. Для зразків голозерного ячменю 2017...2018 року масова частка жиру складає 2,7...3,2 \%, для вівса сорту «Саломон» та «Самуель» характерний підвищена масова частка жиру - 6,0..6,3\%. Переважаючою речовиною вуглеводного комплексу вівса та ячменю є крохмаль. Масова частка крохмалю в зерні круп'яного ячменя становить 54,6 \%, продукти переробки ячменю вміщують 63,8-65,7\%. В досліджуваних зразках голозерного ячменю сорту «Ахіллес» 2011...2014 років масова частка крохмалю змінювалася у межах від 57,6 до 60,5 \%. Зерно 2017...2018 року характеризується масовою часткою крохмалю на рівні $58 . .61$ \%. У вівсяному зерні крохмаль оточений шарами $\beta$-глюканів та оболонковими частинами, основна його частка знаходиться в ендоспермі. Встановлено, що голозерний овес сорту «Саломон» 2011...2014 років вирощування характеризувався однаковою масовою часткою крохмалю із лущеним контрольним зерном - 58,5...61,1\%, але більшим в 1,2...1,3 рази в порівнянні 3 нелущеним плівчастим зерном. Зразки голозерного вівса 2017...2018 року вирощування також характеризуються підвищеною масовою часткою крохмалю - 59,3...61,6 \%. Мінеральні речовини $\epsilon$ складовою частиною зерна, масова частка яких у продовольчому зерні вівса складає 3,2 \%, пластівцях «Пелюсткові» - 1,9 \%, «Геркулес» та «Екстра» - 2,1%. В зерні ячменю продовольчого призначення характерним є вміст мінеральних речовин на рівні 2,4 \%. Крупи перлові та ячні вміщують 0,9...1,2\% мінеральних речовин [12]. Зразки зерна голозерного ячменю та вівса 2011...2014 років завдяки відсутності на поверхні квіткових плівок характеризувалися відносно низькою зольністю - 2,3...2,7 \% та 2,1...2,4 \% відповідно. Зерно 2017...2018 року також в порівнянні з плівчастим зерном характеризується меншою зольністю 2,2...2,5 \% для голозерного ячменю сорту «Ахіллес» і 2,3...2,6 \% для голозерного вівса сортів «Саломон» і «Самуель».

\section{References}

1. Pravila organiIzatsii i vedennya tehnologIchnogo protsesu na krup'yanih zavodah. (1998). K., 164.

2. Shutenko, E.I. (2010). Tehnologiya krup'yanogo virobnitstva: navch. PosIbnik. K.: Osvita Ukrainy, 272.

3. Kaukovirta-Norja, A. (2004). Germination: a means to improve the functionality of oat. Agricultural and food science. 13, 100 - 112. https://doi.org/10.2137/1239099041838049

4. Hager, A.S. (2014). Gluten free beer -A review. Trends in Food Science \& Technology. 36, 44 - 54. https://doi.org/10.1016/j.tifs.2014.01.001

5. Schnitzenbaumer, B. (2014). Implementation of commercial oat and sorghum flours in brewing. European Food Research and Technology. 238, 515 - 525. https://doi.org/10.1007/s00217-013-2129-0

6. Onning, G. (1999). Consumption of oat milk for 5 weeks lower serum cholesterol and LDL cholesterol in free living men with moderate hypercholesterolemia. Ann Nutr Metab. 43,301 - 309. https://doi.org/10.1159/000012798

7. Hamaker, B.R. (2007). Technology of functional cereal products. Elsevier, 568. https://doi.org/10.1201/9781439824177

8. DSTU 376998 YachmIn. TehnIchnI umovi. Derzhspodivstandart Ukrainy, K.: 1998, 18.

9. Pomeranz, Y. (1991). Functional properties of food components. San Diego, CA: Academic Press, 560.

10. Steele, K. (2013). Breeding low-glycemic index barley for functional food. Field Crops Research, 154, 31 - 39. https://doi.org/10.1016/j.fcr.2013.07.018

11. Peltonen-Sainio, P. (2004). Characterising strengths, weakness, opportunities and threats in producing naked oats as a novel crop for northern growing conditions. Agricultural and Food Science, 13, 212 - 228. https://doi.org/10.2137/1239099041838111

12. Skurihin, I.M. (2002). Himicheskiy sostav rossiyskih pischevyih produktov. Spravochnik H46 M.: DeLi print, 236.

Cite as

Соц С.М., Чумаченко Ю.Д., Кустов І.О., Кузьменко Ю.Я. Зерно голозерного вівса та голозерного ячменю. Особливості технологічних властивостей зерна // Наук. пр. / Одес. нац. акад. харч. технологій. Одеса, 2020. Т. 84, вип. 2. С. 5 - 9.

Отримано в редакцію 11.07 .2020

Received 11.07.2020

Прийнято до друку 10.09 .2020

Approved 10.09.2020 